Chirurgia (2019) 114: 693-703

No. 6, November-December

Copyright $@$ Celsius

http://dx.doi.org/10.21614/chirurgia.114.6.693

\title{
Postoperative Bleeding Risk after Sleeve Gastrectomy. A Two Techniques of Stapled Line Reinforcement Comparative Study in 4996 Patients
}

\author{
Bogdana Banescu', Irina Balescu', Catalin Copaescu ${ }^{1,2}$ \\ ${ }^{1}$ Ponderas Academic Hospital Bucharest, Romania \\ 2"Grigore T Popa" University of Medicine and Pharmacy, lasi, Romania
}

Corresponding author:

Catalin Copaescu, MD PhD

Associated Professor of Surgery

Ponderas Academic Hospital

Nicolae Caramfil Street, no. 85 A

district 1, Bucharest, Romania

E-mail: catalin.copaescu@ponderas-ah.ro

\section{Abbreviations:}

LSG - laparoscopic sleeve gastrectomy; $\mathrm{BP}$ - blood pressure;

$\mathrm{ML}$ - medium-large;

LMWH - low molecular weight heparin; PPHP - Postoperative Hemorrhages Prevention.
Received: 02.12.2019 Accepted: 20.12 .2019

\section{Rezumat}

Riscul de sângerare postoperatorie după gastric sleeve. Studiu comparativ a două tehnici de hemostază pe linia de agrafare la 4996 pacienți

Scopul studiului: De a compara eficiența a două tehnici de control a hemostazei la nivelul liniei de agrafare după gastrectomia longitudinală laparoscopică (sleeve gastrectomy): sutura peste linia de agrafare şi plasarea de clipuri hemostatice la nivelul surselor de sângerare vizibile.

Material şi Metodă: Datele pacienților supuşi acestui tip de interventie chirurgicală în Ponderas Academic Hospital din Ianuarie 2012 până în Noiembrie 2019 au fost analizate retrospectiv. Până în anul 2014 inclusiv, controlul surselor de sângerare de la nivelul liniei de agrafare a fost efectuat prin plasarea de clipuri hemostatice, iar începând cu anul 2015 hemostaza a fost efectuată prin intermediul suturii cu fir continuu peste această linie. În ambele grupe tensiunea arterială (BP) a fost crescută intra-operator cu 30\% față de nivelul preoperator pentru a verifica hemostaza chirurgicală la final.

Rezultate: Intre 2012 şi 2019 au fost efectuate 4996 de gastrectomii longitudinale în centrul nostru, 1093 cazuri (grupul A) fiind operate în primul interval (2012-2014), iar restul de 3903 proceduri (grupul B) fiind efectuate în cel de-al doilea interval (2015 - prezent). În grupul A au existat nouă pacienți $(0,8 \%)$ care au dezvoltat hemoperitoneu postoperator precoce, la cinci dintre ei sursa fiind localizată la nivelul liniei de agrafare; în rândul pacienților încadrați în grupul B, reintervenția precoce pentru hemoperitoneu a fost necesară în 15 cazuri $(0,38 \%)$, în nici unul dintre aceste 
cazuri sursa fiind prezentă pe linia de agrafare; diferența între cele două grupuri a fost semnificativă statistic $(\mathrm{p}=0,002)$.

Concluzii: Creşterea valorii tensiunii arteriale cu 30\% ajută la identificarea şi controlul surselor de sângerare, reducând astfel incidența hemoragiei postoperatorii după gastrectomia longitudinală. Sutura continuă peste linia de agrafare (over-sewing) asigură o hemostază mai bună după gastrectomia longitudinală comparativ cu aplicarea clipurilor metalice. Nici o sângerare cu originea la nivelul liniei de agrafare nu a fost înregistrată după sutura sistematică a liniei de agrafare.

Cuvinte cheie: chirurgie bariatrică, gastrectomie longitudinală, sutura liniei de agrafare, clipuri hemostatice, sângerare postoperatorie

\section{Abstract}

Aim of the study: To compare the effectiveness of two different techniques used to control the postoperative bleeding after laparoscopic sleeve gastrectomy (LSG): over-sewing the stapled line and applying hemostatic clips on the visible bleeders along the stapled line.

Material and Methods: Prospectively collected data of the patients submitted to LSG in Ponderas Academic Hospital, since January 2012 to November 2019 were retrospectively reviewed. Before and including the year of 2014, the control of the stapled line bleeding sources was provided by hemostatic clips while, starting with 2015 , hemostasis was controlled by over-sewing the stapled line. For both groups, the blood pressure (BP) was intraoperatively raised up with $30 \%$ as compared to the preoperative level, in order to finally verify the surgical hemostasis.

Results: Between 2012 and 2019, 4996 gastric sleeve procedures were performed in our center, 1093 operations (Group A) being performed during the first interval (2012-2014) while the remaining 3903 procedures (Group B) have been performed during the second interval (2015 to 2019). Nine patients of the Group A (0.8\%) developed early postoperative hemoperitoneum, in five of these cases the source being localized on the stapled line; among patients in the Group B early postoperative re-operation for hemoperitoneum was needed in 15 cases $(0.38 \%)$, but in none of these cases the source was located at the stapled line; the difference was statistically significant $(\mathrm{p}=0.002)$.

Conclusions: The intraoperative risen of the blood pressure (BP) with $30 \%$ helps identifying and controlling the bleeding sources thus reducing the incidence of postoperative bleeding in LSG. Oversewing the stapled line provided better hemostasis in LSG as compared with the application of metallic clips. No stapled line bleeding was encountered after systematically over-sewing it.

Key words: bariatric surgery, gastric sleeve, over-sewing the stapled line, hemostatic clips, postoperative bleeding

\section{Introduction}

Nowadays, obesity represents a significant health problem affecting people worldwide; in the meantime association between obesity and certain pathological conditions such as diabetes mellitus, atherosclerosis, arterial hypertension, sleep apnea and other respira- tory dysfunctions enabled surgeons worldwide to focus their attention on surgical procedures which might induce durable weight loss as well as the improvement of the obesity related comorbidities (1).

Described initially in 2003 by Michel Gagner, as the first step procedure of the duodenal switch in super morbidly obese 
patients, laparoscopic gastric sleeve (LSG) has gained surgeons' interest also as a stand-alone procedure $(2,3)$. The method proved to be safe and effective in inducing a durable weight loss, as well as to improve the metabolic disorders associated in the vast majority of patients (4). However, it should not be omitted the fact that, especially due to these associated comorbidities, the obese patients submitted to bariatric surgery are in fact very fragile, with high risks of developing early postoperative complications (5-7). Among the most fearful complications which might be encountered during the early postoperative period, the postoperative hemorrhage as well as gastric leaks are the most frequently reported ones (8). When it comes to the postoperative hemorrhage, it can originate from both the stapled line and from the dissecting area, the overall, the reported incidence of this complication goes up to $2 \%$ (9-11) (Fig. $1 A, B$ ). In order to decrease the risk of further developing such complications, multiple methods have been proposed, the most frequently used ones being represented by: over-sewing, placing fibrin glue, using buttress material, placing clips or even using energy devices (11-13). Among these strategies, using the buttress materials, over sewing as well as applying titanium clips on the stapled line have been the most widely investigated. However, conflicting results have been reported, so far; therefore, no standardization technique could be proposed; moreover, these conflicting results enabled the surgeons to consider that other factors might be also responsible for the apparition of bleeding complications after LSG (14-16).

Ten years ago, we have explored the possibility of using buttress material to control the postoperative bleeding after LSG. The outcomes were not encouraging us to continue, as the stapled line bleeding was remaining at $1.6 \%$. Inspired by the work of Jan Mulier and Bruno Dillemans who studied the effect of systolic arterial pressure on bleeding of the gastric stapling during laparoscopic gastric bypass surgery (17) we have created and introduced in 2009 a Protocol for the Postoperative Hemorrhages Prevention after Laparoscopic Sleeve Gastrectomy. According to this protocol, the blood pressure (BP) is intraoperatively raised up with $30 \%$ as compared to the preoperative level, and the evident bleeding sources are controlled with Titanium mediumlarge (ML) from hemostatic clips. The results of using this protocol for the following years were good, reducing the rate of postoperative bleeding by more than $50 \%$, from $1,6 \%$ to $0.8 \%$ (18). Later, since the year of 2015 , we have changed the LSG technique giving up using hemostatic clips and introducing the routinely over-sewing the stapled line.

The aim of this study was to compare two techniques used to control the postoperative bleeding after laparoscopic sleeve gastrectomy
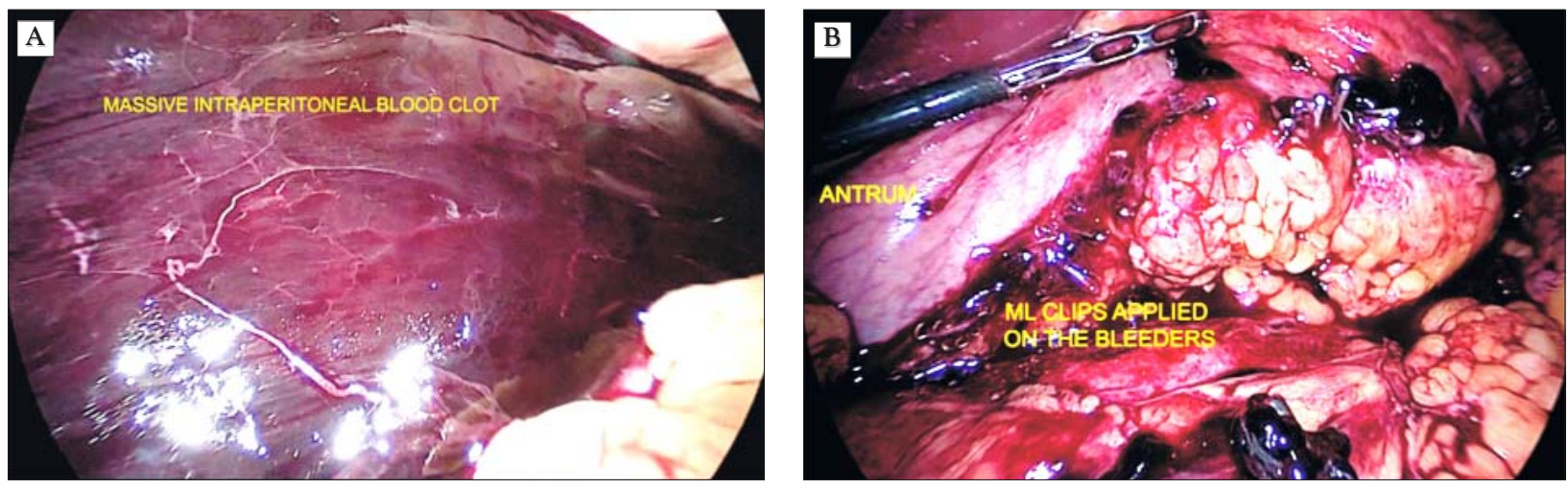

Figure 1. Early laparoscopic reintervention for postoperative hemorrhage after LSG. (A) A massive blood and clots intraabdominal collection is revealed by the laparoscopy; (B) active bleederswereidentifiedatthe gastric stapled line. The bleeding was controlled by multiple appliance of Titanium ML hemostatic clips 
(LSG): over-sewing and using hemostatic clips on the stapled line, in a high-volume bariatric center.

\section{Material and Method}

After obtaining the approval of the Ethical Committee, data of the patients submitted to LSG in Ponderas Academic Hospital from January 1st 2012 to November 30th 2019 were retrospectively reviewed.

\section{Preoperative Assessment}

All bariatric patients were submitted to a standard preoperative work-up consisting of cardiologic evaluation, abdominal ultrasound, upper digestive endoscopy, cardiopulmonary radiography, barium enema, anesthesiology evaluation as well as to extensive blood tests. Particular attention was given to the evaluation and preoperative control of the blood pressure as a significant number of cases presenting newly diagnosed or poorly therapeutically controlled arterial hypertension. In such cases a 24-hour Holter monitoring of the blood pressure (BP) was placed in order to provide a more accurate information regarding the severity of this pathology and to achieve a better preoperative control of BP. In the meantime, in all candidates for bariatric surgery, a dose of low molecular weight heparin (LMWH) was administrated 12 hours before surgery, in order to diminish the risk of postoperative thrombotic events. In patients with a body mass index lower than $40 \mathrm{~kg} / \mathrm{m}^{2}$ an injection of 5000 units of dalteparin sodium was administrated while in cases with a higher body mass index the dose was raised to 7500 units.

\section{Intraoperative Assessment}

As already mentioned, before 2015, the intraoperative bleeding control was achieved by placing ML titanium clips on the visible bleeding sources on the entire length of the stapled line (Fig. $2 \mathrm{~A}, \mathrm{~B}$ ) while, from the beginning of 2015 , hemostasis was achieved by over sewing the stapled line with 3.0 monofilament polypropylene running suture (Fig. $3 \mathrm{~A}$, $B)$. The patients who underwent LSG within the two distinct time intervals were analyzed as Group A and Group B, respectively.

In order to maximize the efficiency of the intraoperative hemostasis, the Protocol for the Postoperative Hemorrhages Prevention (PPHP) was applied, and the BP was routinely raised up to $30 \%$ above the preoperative level, in both groups. Norepinephrine was used by the anesthesiologists to stimulate the bleeders, increasing the opportunity of hemostasis (18). For the Group A, titanium clips were placed on the stapled line while the blood pressure was
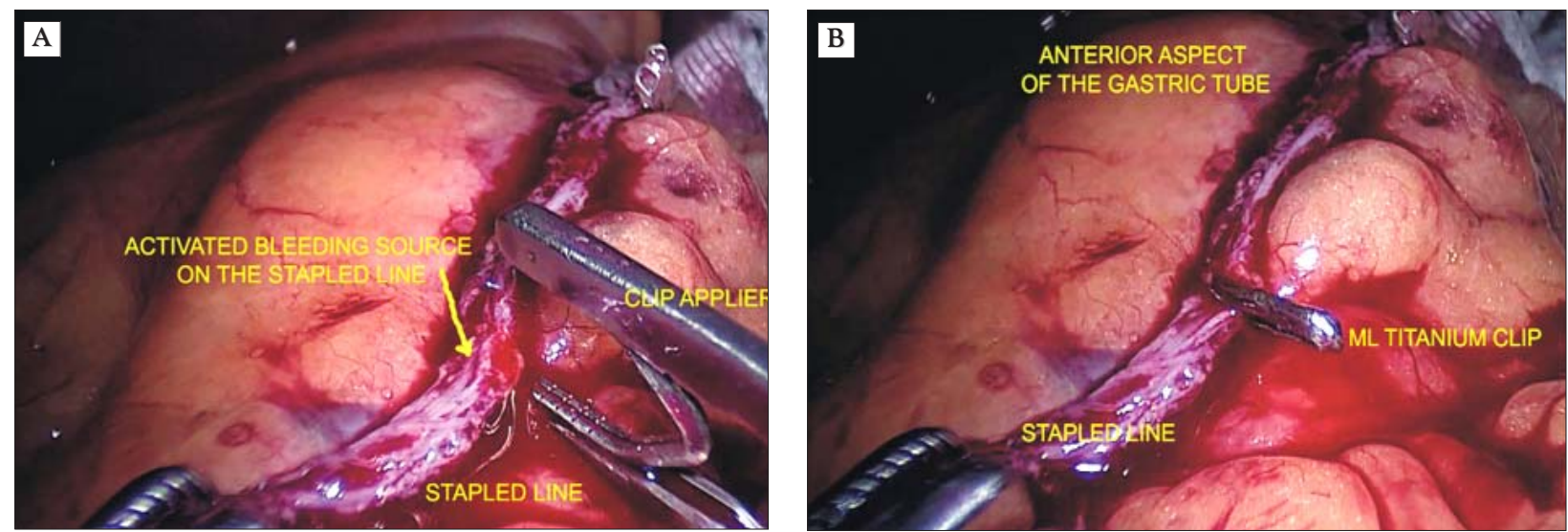

Figure 2. Laparoscopic Sleeve Gastrectomy - The bleeding control is achieved by placing ML Titanium clips on the visible bleeding sources on the entire length of the stapled line (Group A). (A) the bleeding source is identified after risingthe BP with $30 \%$; (B) ML clip controls the bleeding source. Its' arms should not overpass the stapled line. 

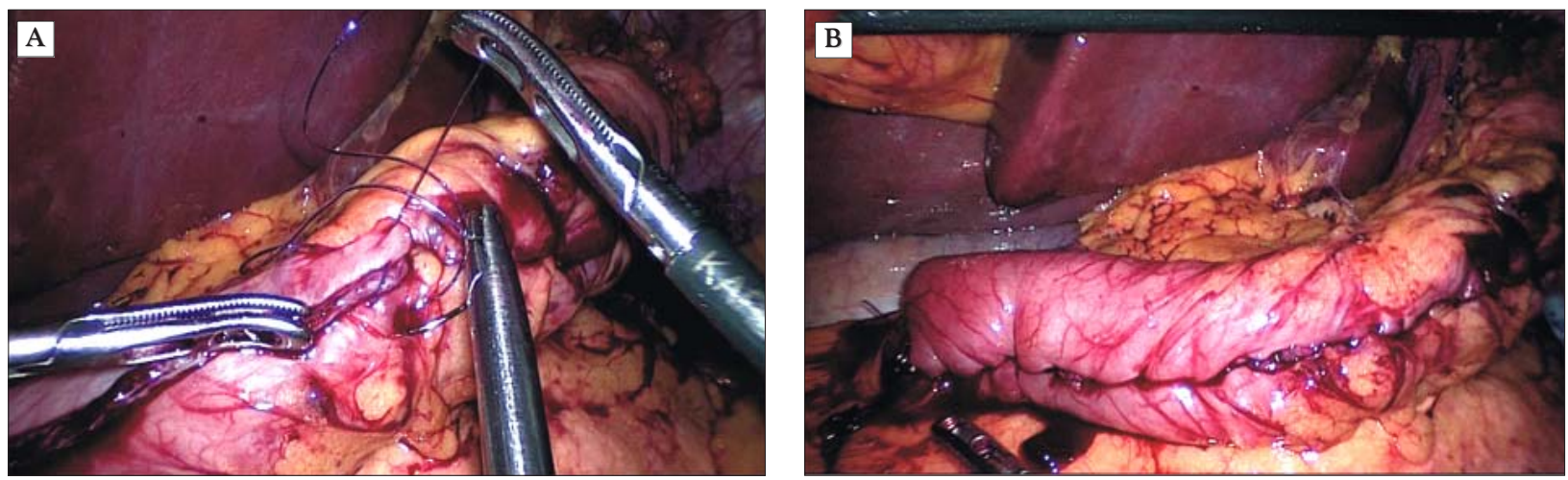

Figure 3. Laparoscopic Sleeve Gastrectomy - The hemostasis is achieved by over sewing the stapled line. (Group B). (A) A 3.0 monofilament running suture is inverting the stapled line; (B) The final aspect of the LSG after entirely over-sewing the stapled line

increased. In the Group B the over-sewing was finalized before the blood pressure was raised by the anesthesiologist. In both eventualities the stapling line, as well as the gastrocolic ligament, the short gastric vessels, the access ports and all the other potential sources of bleeding were checked up. In the meantime, in all cases a left subhepatic drainage tube was left in place for the next 24 hours.

\section{Postoperative Assessment}

The administration of LMWH (dalterparin sodium) which had been initiated the day before surgery, was continued since the first day postoperatively until the 21 st day in all cases in order to prevent the development of further thrombo-embolic events.

An active protocol of early detection of the postoperative bleeding (APEDB) is applied for the first 48 hours postoperatively and it consists of scheduled serial blood tests and abdominal ultrasound examination.

The postoperative hemorrhage is suspected in the cases presenting a hemoglobin drop of at least $2 \mathrm{~g} / \mathrm{dl}$ (when compared to the preoperative level of hemoglobin), hemoglobin drop below $10 \mathrm{~g} / \mathrm{dl}$ in the early postoperative period or a higher than $30 \%$ drop of the hematocrit values (early postoperatively versus preoperatively), in the absence of any other identifiable bleeding source. The US examination is used to confirm the hemo- peritoneum. Once the postoperative hemorrhage was intuited, the therapeutic strategy consisted of emergency laparoscopic reoperation in hemo-dynamically unstable patients or conservative strategy (fluid resuscitation alone or in association with blood transfusion) in stable patients. As for the cases in which reoperation was needed, surgery was performed in order to provide the control of the bleeding source, as well as, the evacuation of the intraabdominal hematic collection.

\section{Statistical Analysis}

Data collected during the study period was analyzed using SPSS17 (Statistical Package for Social science Chicago, United States of America. Chi squared statistic test was used for categorical variables while the unpaired $t$ test was used in order to compare continuous variables, a $p$ value $<0,05$ being considered as statistically significant.

\section{Results}

Between 2012 and 2019, 4996 patients underwent laparoscopic sleeve gastrectomy in our Center. Group A included 1093 patients, operated between January 2012 and December 2014 and, titanium clips were used to control the hemostasis on the stapled line in these patients. Among these cases, nine patients 
(0.8\%) required reoperation for early postoperative bleeding. In five cases a bleeding source from the stapled line was identified while in the remaining four, there was no identifiable bleeding source.

During the second period (January 2015 December 2019) 3903 patients were submitted to gastric sleeve (Group B), and over-sewing the stapled line was the method used for hemostasis. Reoperation for postoperative bleeding was needed in 15 cases $(0.38 \%)$ of the Group B; however, no case of stapling line bleeding was encountered.

Demographic data of patients submitted to sleeve gastrectomy within the two groups are shown in the Table 1. As it can be observed from the these data, there was no statistically significant difference between the mean age $(p=0,63)$ and association of arterial hypertension $(p=0,23)$ and diabetes mellitus $(0,62)$ between the two groups. In the meantime, the sex distribution was similar between the two groups (36\% male patients in Group A versus $38 \%$ male patients in Group B). The only statistically significant difference is due to a reduction of more than $50 \%$ of the postoperative bleeding rate in the group B $(0.38 \%$ vs $0.8 \%, \mathrm{p}=0,033)$.

Among the encountered bleeding sources in the Group B the most commonly incriminated ones were represented by the abdominal wall

Table 1. Demographic data and comorbidities of patients submitted to gastric sleeve between 2012-2014 (group A) and 2015-2019 (group B)

\begin{tabular}{lrr}
\hline Parameter & Group A & Group B \\
\hline No. of cases & 1093 & 3903 \\
\hline Mean age, years (range) & $\begin{array}{r}41,4 \\
\text { Sex: }\end{array}$ & $\begin{array}{r}40 \\
\text { - Male }\end{array}$ \\
$\quad$ - Female & $395(36 \%)$ & $1457(38 \%)$ \\
\hline Arterial hypertension: & $698(64 \%)$ & $2446(62 \%)$ \\
$\quad$ - Yes & & \\
- No & $342(31 \%)$ & $796(21 \%)$ \\
Type II Diabetes Mellitus: & $751(69 \%)$ & $3107(79 \%)$ \\
$\quad$ - Yes & & \\
$\quad$ - No & $171(16 \%)$ & $388(10 \%)$ \\
Number of cases & $922(84 \%)$ & $3515(90 \%)$ \\
necessitating reintervention & & \\
due to postoperative bleeding & & \\
\hline
\end{tabular}
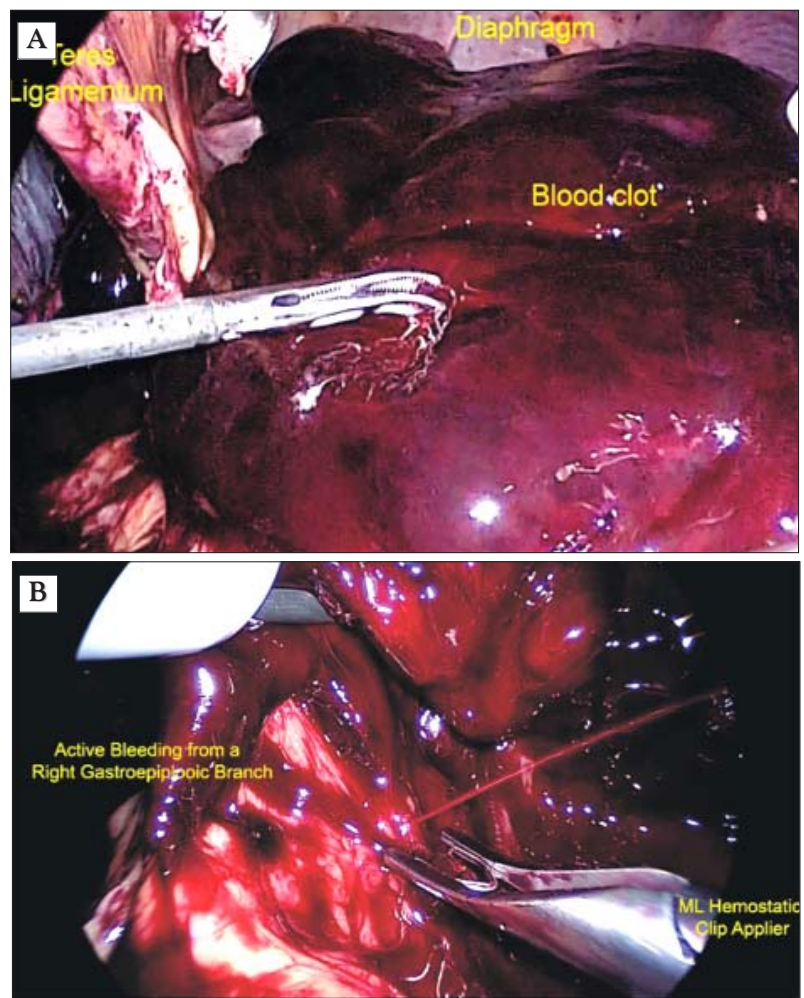

Figure 4. Early laparoscopic reintervention after LSG for outside of the stapled line active bleedingand hemodynamic shock. (A) massive hemoperitoneum revealed by the laparoscopy; (B) active bleeding source was originating from a gastro-epiploic branch and controlled by Titanium ML hemostatic clips

- at the access ports (in six cases) followed by gastrocolic ligament (in five cases) (Fig. 4A, B) and fat pad dissection (in one case); moreover, in three cases the bleeding source couldn't be identified intraoperatively although blood pressure was raised.

The difference between the rates of postoperative bleeding - between the two groups was a statistically significant one $(p=0.002)$. No significant complications related to the type of reinforcement were encountered in the group $\mathrm{A}$ and but 31 obstructions (0.7\%) endoscopically treated by dilatations were identified in the Group B (19).

No mortality was encountered in the studied groups.

\section{Discussions}

Defined as a hemoglobin drop of at least $2 \mathrm{~g}$ in 
association with clinical signs such as pallor, hemodynamic instability and imaging certified intraperitoneal free fluid or collection, the postoperative bleeding after sleeve gastrectomy represents one of the most fearful complications of bariatric surgery.

The complexity of a case which develops such a complication during the postoperative period can widely vary according to the amount of blood loss, as well as, the clinical and biological status of the patient. Therefore, patients developing postoperative bleeding after LSG can be classified as a Dindo Clavien grade I complication, if only crystalloids and tranexamic acid are needed in order to control the situation to Dindo Clavien grade II complications if transfusion or red blood cell administration is needed and even Dindo Clavien grade III-IV complications if reoperation and a longer in stay in the intensive care unit department is needed $(20,21)$.

Although initially almost all patients are hemodynamically stable, with the evidence of a good clinical and biological condition, only in few hours, the general status can worsen and, the type of complication might rapidly change from a Dindo Clavien I grade to a III or even IV grade; moreover, in isolated cases presenting poorer baseline clinical condition death might occur (21). Therefore, close and attentive monitoring in such cases is mandatory, to prevent the missing of the moment when reoperation is needed.

Postoperative bleeding might originate from the stapled line but, also from other sites of the greater curvature dissection (including the gastrocolic ligament, short gastric vessels, and fat pad) or even from the sites through which the trocars enter the abdominal cavity. However, the site of bleeding cannot be known before reoperating the patient; moreover, in a significant number of cases the bleeding origin cannot be ruled out even during the re-operation. In such cases the source would become inactive and, the surgeon will not be able to reactivate it, as the $\mathrm{BP}$ was decreasing during the bleeding, and the conditions to spontaneously consolidate the hemostasis are created.

Due to the fact that, in a significant number of cases the source of bleeding cannot be evident at the time of surgery and in order to prevent the risk of developing postoperative hemorrhagic complications, we paid specific attention on identifying the most appropriate therapeutic strategy for bleeding prevention and control. Therefore, since 2009 we created the above mentioned Protocol for Postoperative Hemorrhages Prevention after Laparoscopic Sleeve Gastrectomy which consists of intraoperative raise of the $\mathrm{BP}$ with at least $30 \%$ as compared to the preoperative level and placing metallic clips on the activated bleeders. The introduction of the protocol (PPHP) was associated with significant improvement of the postoperative bleeding risk, consisting of decreasing by $50 \%$ the rates of postoperative bleedings (from 1.6\% to $0.8 \%$ ); (18) However, looking for better outcomes, we further modified the protocol of bleeding prevention by replacing the Titanum hemostatic clips appliance with over-sewing the entire stapled line. The two techniques are investigated in the present study which demonstrated that, among the cases in Group $\mathrm{B}$, the rate of postoperative bleeding was of only $0,38 \%$, more than $50 \%$ reduced when compared to $0,8 \%$ among patients in Group A.

The effectiveness of this protocol can be easily demonstrated by comparing the data we achieved to the ones reported so far in literature. In the meta-analysis conducted by Shikora et al. which was published in 2015 the authors identified 253 studies which were conducted on the subject of postoperative complications after sleeve gastrectomy; according to this study, the overall rates of postoperative bleeding was $4.94 \%$ among authors who chose not to enforce the stapled line, 2,41\% among authors who chose to over sew, 2,09\% among authors who chose placing glycolide co-polymers and $1,16 \%$ among those who used bovine pericardium (21). In a more recent study conducted by Khoursheed et al. and published in 2016, the authors included 664 LSG patients, in whom over sewing the stapled line was the option of choice; among these cases, the postoperative bleeding occurred in $2 \%$ of cases and $0,5 \%$ required re-operation; 
moreover one patient necessitated conversion to open surgery. However, the postoperative mortality rate was null (8). These data come to underline once again the efficacy and safety of routine over sewing the stapled line.

In our study, in four cases of the Group A and, in three cases of the Group B, the source could not be revealed at the time of re-operation. In such cases is difficult to understand what it should be done in order to diminish the risk how long we do not know which is in fact the source (9).

As for the need of routinely placement of a drainage tube, this fact is also intensely debated; therefore, certain authors consider that placing these devices will not be able to provide a faster diagnostic of this complication due to the fact that the tube can be rapidly clogged with blood clots (22). Moreover, these drainage tubes are usually removed within the 24 hours while a significant number of cases develop this complication after this interval of time (9).

In order to diminish the rate of development of postoperative bleeding, various methods have been proposed; therefore the most frequently proposed methods are: placing clips on the stapling line, using electrocoagulation at this level, using buttress material or over sewing the stapling line. Data reported so far regarding the most efficient procedure are conflicting, a standard therapeutic protocol being not yet well defined (23-25).

However, it seems that using electrocoagulation at this level might increase the risk of subsequent ischemia and further leak development; although lower when compared to cases in which electrosurgery is used, the risk of ischemia and leak development also seems to be higher in cases in which metallic clips are placed all along the stapling line when compared to cases submitted to over sewing. This aspect can be explained by the direct coupling effect which consists of the touch between one conductive element (the Titanum clip) and the monopolar device, leading to current deviation to non-target tissue (the stapled line). The energy which will therefore affect the tissues at the level of the stapled line will predispose to the development of further micro-necrosis, hard to be observed intraoperatively but which will further lead to the development of a gastric leak (25).

The method of clip placement seems not to provide an efficient diminishing of the risk of postoperative hemorrhage, bleeding being possible from the level of the stapling line where clips had not been placed $(9,21)$ (Fig. 1 A,B).

A more effective and safe method seems to be represented by over sewing on the whole length of the stapling line. The method is not expensive, reproducible and well standardized, providing in the meantime an efficient tool to diminishing the risk of both early and late gastric leaks (9). However, certain authors consider that over sewing is associated with longer operative times and therefore, with higher costs due to a longer stay in the operating room (26-28). More elaborated cost analysis came to demonstrate that although the time spent in the operating room and therefore the cost of surgery is higher if over sewing is performed, these costs are amortized by the use of a cheaper material (the price of a stitch being lower when compared to buttress material or other glues) as well as, by the lower rates of postoperative bleedings necessitating administration of blood products or even re-operation (9).

However, not all the studies conducted on the issue of postoperative bleeding prevention reported similar results in terms of efficacy; therefore, in Shikora's meta-analysis which was published in 2015 the authors came to demonstrate that over-sewing is more effective than clips placement or no reinforcement but less effective when compared to bovine pericardium reinforcement (23).

In a similar meta-analysis, Gagner, $M$ et al., came to conflicting conclusions, demonstrating better result for absorbable polymer membrane (APM) as compared to nonabsorbable bovine pericardial strips (24).

As we have experienced the use of different buttress materials to reinforce the stapled line 
in LSG, we concluded that these materials should be selectively used. In the thick antrum, their presence overloads the available cartridges and alter the stapler formation. Subsequently, laceration of the stapled line siding tissue is at risk (Fig. 5). The surgeons should better look for an adequate stapler formation with less tissue compression, leaving the blood to properly reach the surgical site. As this strategy invites to go more to the left (Fig. 5) and using higher staplers, more bleeders might need intraoperative control. This last task will be fulfilled by metallic clips or better by oversewing technique.

Due to the conflicting published results, the attention was focused on determining which other factors might influence the risk of developing postoperative hemorrhage after sleeve gastrectomy.

An extremely interesting study which was focused on identifying other potential prognostic factors was published in 2017 by Spivak et al. in Obesity Surgery journal (21); the authors came to demonstrate that there is no difference in terms of postoperative risk of

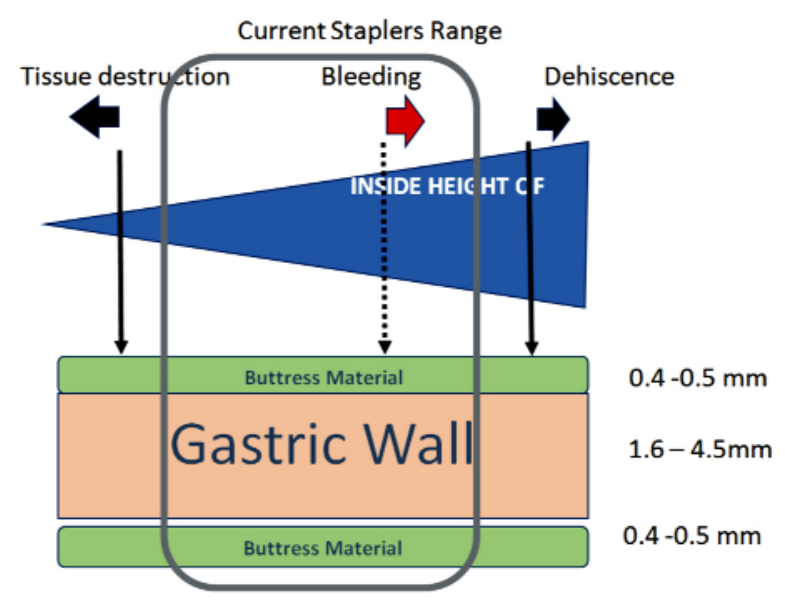

Figure 5. Schematic representation of the effect of actual staplers' height on the gastric wall. The smaller ones produce tissue laceration while the large ones may not close properly. The surgeons may provide better healing conditions and may choose toward bleeding, which can be controlled intraoperatively. The presence of buttress material should be always judged accordingly bleeding depending on the surgical technique, this risk being significantly influenced by the association of type 2 diabetes mellitus; moreover, the same study underlined the fact that patients with lower than $40 \mathrm{~kg} / \mathrm{m}^{2}$ body mass index exhibited a higher risk of developing postoperative bleeding when compared to morbidly obese patients, this fact being explained through a higher incidence of diabetes mellitus among this subgroup of patients (21). These data were surprising even for the authors themselves, the hyper coagulable status of diabetic patients being well known. However it seems that the risk of postoperative bleeding in such cases is rather related to a poorer immediately wound healing (typical for diabetic patients), the other factors such as hyper-reactive platelets, reduced fibrinolysis and increased plasminogen activator I inhibitor (which are responsible for the hyper-coagulable status) being not activated during the first hours postoperatively (29-32).

As for the impact of arterial hypertension on the risk of postoperative bleeding, although initially it had been considered that cases with poorly controlled arterial hypertension are at risk to develop postoperative bleeding (33), more recent studies came to infirm this hypothesis (34).

An interesting study which presented a preventive strategy for bleeding form the stapled line comes from Karaman $\mathrm{K}$ et al. and was published in 2017 (35); in this study, the authors came to demonstrate that if the systolic BP at the time of stapling the stomach is higher than $120 \mathrm{mmHg}$ the risk of postoperative bleeding as well as the necessity of using hemostatic agents is significantly increased; the authors found that this parameter was statistically significant in both univariate and multivariate analysis. Although the method seems safe and efficient in order to minimize the risk of postoperative complications as well as in decreasing the operative time and the costs of surgery, attention should be paid to the potential missing certain bleeding sources; therefore, among these cases a significant per cent will develop much higher 
than $120 \mathrm{mmHg}$ values of the $\mathrm{BP}$, bleeding being possible from otherwise unidentifiable sources (35).

Another factor which has been widely incriminated in regard to the risk of postoperative complications such as postoperative hemorrhage is represented by the surgeon and hospital care factors; however, in our study we believe that these confusion factors were removed through the fact that all patients were submitted to surgery in a high-volume center of excellence in bariatric surgery (the human factor represented by the surgeon's experience being therefore minimized) and were submitted to a standard preoperative, intraoperative and postoperative protocol (minimizing in this way the hospital care factor) (21).

The present study demonstrated the importance of routinely use of the Protocol for Postoperative Hemorrhages Prevention in a high -volume bariatric center. Aiming to identify the best technique to prevent the postoperative bleeding after LSG, the present study proved the superiority of the ower-sewing running suture to other techniques, eliminating the stapled bleedings for a large series of patients (Group B, 3903 patients). To our knowledge this is the largest single center study of this design. However, the study os not randomized and other researchers are expected to confirm our results.

\section{Conclusions}

Postoperative bleeding after bariatric surgery represents one of the most fearful complications which could develop within the first postoperative days.

The intraoperative risen of the blood pressure (BP) with 30\% helps identifying and controlling the bleeding sources thus reducing the incidence of postoperative bleeding in LSG.

Over-sewing the stapled line provided better hemostasis in LSG as compared with the application of metallic clips. No stapled line bleeding was encountered after systematically over-sewing it.

\section{Conflict of Interest}

The authors declared no conflict of interest

\section{References}

1. Sjostrom L, Narbro K, Sjostrom CD, Karason K, Larsson B, Wedel $\mathrm{H}$, et al. Effects of bariatric surgery on mortality in Swedish obese subjects. N Engl J Med. 2007;357(8):741-52.

2. Regan JP, Inabnet WB, Gagner M, Pomp A. Early experience with two-stage laparoscopic Roux-en-Y gastric bypass as an alternative in the super-super obese patient. Obes Surg. 2003;13(6):861-4.

3. Copaescu C. Laparoscopic sleeve gastrectomy for morbid obesity. Chirurgia (Bucur). 2009;104(1):79-85.

4. Boyle M, Carruthers N, Mahawar KK. Five-Year Outcomes with Stand-alone Primary Sleeve Gastrectomy. Obes Surg. 2019;29(5): 1607-13.

5. Sirbu A, Nicolae H, Martin S, Barbu C, Copaescu C, Florea S, et al. IGF-1 and Insulin Resistance Are Major Determinants of Common Carotid Artery Thickness in Morbidly Obese Young Patients. Angiology. 2016;67(3):259-65.

6. Major P, Wysocki M, Pedziwiatr M, Pisarska M, Dworak J, Malczak $\mathrm{P}$, et al. Risk factors for complications of laparoscopic sleeve gastrectomy and laparoscopic Roux-en-Y gastric bypass. Int J Surg. 2017;37:71-8.

7. Campanile FC, Boru CE, Rizzello M, Puzziello A, Copaescu C, Cavallaro G, et al. Acute complications after laparoscopic bariatric procedures: update for the general surgeon. Langenbecks Arch Surg. 2013;398(5):669-86.

8. Chang SH, Freeman NLB, Lee JA, Stoll CRT, Calhoun AJ, Eagon JC, et al. Early major complications after bariatric surgery in the USA, 2003-2014: a systematic review and meta-analysis. Obes Rev. 2018;19(4):529-37.

9. Khoursheed M, Al-Bader I, Mouzannar A, Ashraf A, Bahzad Y, AlHaddad A, et al. Postoperative Bleeding and Leakage After Sleeve Gastrectomy: a Single-Center Experience. Obes Surg. 2016;26(12): 3007.

10. De Angelis F, Abdelgawad M, Rizzello M, Mattia C, Silecchia G. Perioperative hemorrhagic complications after laparoscopic sleeve gastrectomy: four-year experience of a bariatric center of excellence. Surg Endosc. 2017;31(9):3547-51.

11. Taha 0 , Abdelaal M, Talaat M, Abozeid M. A Randomized Comparison Between Staple-Line Oversewing Versus No Reinforcement During Laparoscopic Vertical Sleeve Gastrectomy. Obes Surg. 2018:28(1):218-25.

12. Cunningham-Hill M, Mazzei M, Zhao H, Lu X, Edwards MA. The Impact of Staple Line Reinforcement Utilization on Bleeding and Leak Rates Following Sleeve Gastrectomy for Severe Obesity: a Propensity and Case-Control Matched Analysis. Obes Surg. 2019; 29(8):2449-63.

13. D'Ugo S, Gentileschi P, Benavoli D, Cerci M, Gaspari A, Berta RD, et al. Comparative use of different techniques for leak and bleeding prevention during laparoscopic sleeve gastrectomy: a multicenter study. Surg Obes Relat Dis. 2014;10(3):450-4.

14. Deitel M, Gagner M, Erickson AL, Crosby RD. Third International Summit: Current status of sleeve gastrectomy. Surg Obes Relat Dis. 2011;7(6):749-59.

15. Choi YY, Bae J, Hur KY, Choi D, Kim YJ. Reinforcing the staple line during laparoscopic sleeve gastrectomy: does it have advantages? A meta-analysis. Obes Surg. 2012;22(8):1206-13.

16. Chen B, Kiriakopoulos A, Tsakayannis D, Wachtel MS, Linos D, Frezza EE. Reinforcement does not necessarily reduce the rate of staple line leaks after sleeve gastrectomy. A review of the literature and clinical experiences. Obes Surg. 2009;19(2):166-72.

17. Dillemans B, Sakran N, Van Cauwenberge S, Sablon T, Defoort B, 
Van Dessel E, et al. Standardization of the fully stapled laparoscopic Roux-en-Y gastric bypass for obesity reduces early immediate postoperative morbidity and mortality: a single center study on 2606 patients. Obesity surgery. 2009;19(10):1355-64.

18. Copaescu C. Protocol for the Postoperative Hemorrhages Prevention after Laparoscopic Sleeve Gastrectomy. 4th Annual International Consensus Summit for Sleeve Gastrectomy; December, 6-8, 2012; New York2012.

19. Turcu F, Balahura C, Doras I, Constantin A, Copaescu C. Symptomatic Stenosis after Laparoscopic Sleeve Gastrectomy Incidence and Management in a High-Volume Bariatric Surgery Center. Chirurgia (Bucur). 2018;113(6):826-36.

20. Clavien PA, Barkun J, de Oliveira ML, Vauthey JN, Dindo D, Schulick RD, et al. The Clavien-Dindo classification of surgical complications: five-year experience. Ann Surg. 2009;250(2):18796.

21. Spivak H, Azran C, Spectre G, Lidermann G, Blumenfeld O. Sleeve Gastrectomy Postoperative Hemorrhage is Linked to Type-2 Diabetes and Not to Surgical Technique. Obes Surg. 2017; 27(11):2927-32.

22. Lacy A, Ibarzabal A, Pando E, Adelsdorfer C, Delitala A, Corcelles R, et al. Revisional surgery after sleeve gastrectomy. Surg Laparosc Endosc Percutan Tech. 2010;20(5):351-6.

23. Shikora SA, Mahoney CB. Clinical Benefit of Gastric Staple Line Reinforcement (SLR) in Gastrointestinal Surgery: a Meta-analysis. Obes Surg. 2015;25(7):1133-41.

24. Gagner M, Buchwald JN. Comparison of laparoscopic sleeve gastrectomy leak rates in four staple-line reinforcement options: a systematic review. Surg Obes Relat Dis. 2014;10(4):713-23.

25. Sepulveda M, Astorga C, Hermosilla JP, Alamo M. Staple Line Reinforcement in Laparoscopic SleeveGastrectomy: Experience in 1023 Consecutive Cases. Obes Surg. 2017;27(6):1474-80.
26. Albanopoulos K, Alevizos L, Flessas J, Menenakos E, Stamou KM, Papailiou J, et al. Reinforcing the staple line during laparoscopic sleeve gastrectomy: prospective randomized clinical study comparing two different techniques. Preliminary results. Obes Surg. 2012;22(1):42-6.

27. Dapri G, Cadiere GB, Himpens J. Reinforcing the staple line during laparoscopic sleeve gastrectomy: prospective randomized clinical study comparing three different techniques. Obes Surg. 2010; 20(4):462-7.

28. Gentileschi P, Camperchioli I, D'Ugo S, Benavoli D, Gaspari AL. Staple-line reinforcement during laparoscopic sleeve gastrectomy using three different techniques: a randomized trial. Surg Endosc. 2012;26(9):2623-9

29. Kaur R, Kaur M, Singh J. Endothelial dysfunction and platelet hyperactivity in type 2 diabetes mellitus: molecular insights and therapeutic strategies. Cardiovasc Diabetol. 2018;17(1):121.

30. Vinik Al, Erbas T, Park TS, Nolan R, Pittenger GL. Platelet dysfunction in type 2 diabetes. Diabetes Care. 2001;24(8):1476-85.

31. Tripodi A, Branchi A, Chantarangkul V, Clerici M, Merati G, Artoni A, et al. Hypercoagulability in patients with type 2 diabetes mellitus detected by a thrombin generation assay. J Thromb Thrombolysis. 2011;31(2):165-72.

32. Carr ME. Diabetes mellitus: a hypercoagulable state. J Diabetes Complications. 2001;15(1):44-54.

33. Jossart GH. Complications of sleeve gastrectomy: bleeding and prevention. Surg Laparosc Endosc Percutan Tech. 2010;20(3): 146-7.

34. Janik MR, Rogula T, Kowalewski P, Waledziak M, Matlok M, Bragoszewski J, et al. Case-Control Study of Postoperative Blood Pressure in Patients with Hemorrhagic Complications after Laparoscopic Sleeve Gastrectomy and Matched Controls. Obes Surg. 2017;27(7):1849-53. 